\title{
MME wt Allele
}

National Cancer Institute

\section{Source}

National Cancer Institute. MME wt Allele. NCI Thesaurus. Code C49727.

Human MME wild-type allele is located within 3q25.1-q25.2 and is approximately $104 \mathrm{~kb}$ in length. This allele, which encodes neprilysin protein, plays a role in the destruction of polypeptides containing up to 30 amino acids. An allelic variant of the MME gene is associated with fetomaternal alloimmunisation with antenatal glomerulopathies and membranous g lomerulonephritis (FMAIG) as well as with renal failure in early adulthood. The MME gene is also associated with susceptibility to late-onset Alzheimer's disease. 